\title{
CHARACTERIZATION OF GOLD NANOPARTICLES FROM CLOVE FLOWER WATER EXTRACT AND ITS ANTIOXIDANT ACTIVITY
}

\author{
G. A. D. Lestari ${ }^{1}$, K. D. Cahyadi ${ }^{1}$ and I. E. Suprihatin ${ }^{2}$ \\ ${ }^{\text {I}}$ Study Program Pharmacy, School of Pharmacy Mahaganesha, Denpasar, Bali, Indonesia. \\ ${ }^{2}$ Department of Chemistry, Faculty of Mathematics and Natural Sciences, Udayana University, \\ Jim-baran, Bali, Indonesia \\ E-mail: lestaridewi87@gmail.com
}

Received: 20 January 2021

Revised: 19 April 2021

Accepted: 26 April 2021

\begin{abstract}
CHARACTERIZATION OF GOLD NANOPARTICLES FROM CLOVE FLOWER WATER EXTRACT AND ITS ANTIOXIDANT ACTIVITY. Green chemistry is a safe and cost-effective method for producing metal nanoparticles. The objective of this study is to synthesize, characterize and tested the antioxidant activity of gold nanoparticles (AuNPs). In this research gold nanoparticles were synthesized using $\mathrm{HAuCl}_{4}$ as the gold precursor and water extract of Syzygium aromaticum (L.) flowers $0.5 \%$ as the bioreductor. Characterization of the gold nanoparticles was carried out using UV-Vis spectrophotometer to measure the maximum wavelength, zeta analyzer to determine the particle size, and SEM EDS to investigate the morphology and content of the gold nanoparticles. The antioxidant activity was determined by measuring its free radical scavenging activity using the DPPH method. The research found the AuNPs has a maximum wavelength at 533 $\mathrm{nm}$, and particle size of $73.52 \mathrm{~nm}$. Furthermore, the AuNPs show free radical scavenging activities of up to $70 \%$.
\end{abstract}

Keywords: Green Synthesis, Gold Nanoparticles, Antioxidant, Syzygium Aromaticum (L.)

\begin{abstract}
ABSTRAK
KARAKTERISASI NANOPARTIKEL EMAS DARI EKSTRAK AIR BUNGA CENGKEH DAN AKTIVITAS ANTIOKSIDANNYA. Sintesis hijau adalah metode yang aman dan hemat biaya untuk memproduksi nanopartikel logam. Penelitian ini bertujuan untuk mensintesis, mengkarakterisasi nanopartikel emas (NPAu) dan menguji aktivitas antioksidan dari NPAu. Dalam penelitian ini nanopartikel emas disintesis menggunakan $\mathrm{HAuCl}_{4}$ sebagai prekursor emas dan ekstrak air bunga Syzygium aromaticum (L.) 0,5\% sebagai bioreduktor. Karakterisasi nanopartikel emas dilakukan menggunakan spektrofotometer UV-Vis untuk mengukur panjang gelombang maksimum NPAu, zeta analyzer untuk mengetahui ukuran partikel, dan SEM EDS untuk mengetahui morfologi dan kandungan nanopartikel emas. Aktivitas antioksidan ditentukan dengan mengukur aktivitas peredaman radikal bebas menggunakan metode DPPH. Hasil penelitian menemukan NPAu memiliki panjang gelombang maksimum $533 \mathrm{~nm}$, dan ukuran partikel 73,52 nm. Selanjutnya, NPAu menunjukkan aktivitas peredaman radikal bebas hingga $70 \%$.
\end{abstract}

Kata kunci: Sintesis Hijau, Nanopartikel Emas, Antioksidan, Syzygium Aromaticum (L.) 


\section{INTRODUCTION}

Nanoparticles are particles with diameters from 1 to $100 \mathrm{~nm}$. These particles are commonly used in the industries, household, and healthcare products. The main challenge during the nanoparticle formation process relates to creating a size, shape and monodispersity that fits the nanoparticle criteria; and therefore improvements in the process of forming nanoparticles are required consistently [1]. Nanoparticles can be prepared using two methods, namely "bottom-up" (chemical method) and "top-down" (physical method) [2,3]. Both chemical and physical methods have succeeded in producing good nanoparticles, but there are drawbacks in chemical and physical methods so that the use of plant or herbal extracts in the fabrication of nanoparticles has emerged as an alternative approach over the last few decades. This nanoparticle biosynthetic method is environmentally friendly and easy to perform [4], cost-effective, and simple. The biosynthesis involves reduction of metal ions by plant secondary metabolites which are obtained by extracting the plant parts in green solvent, ie water. The secondary metabolites such as proteins, reducing sugars, flavonoids, terpenoids, and alkaloids act as reducing agents and capping agents to stabilize the particle size [5-12]. The extracts used to synthesize AuNPs were cloves (Syzygium aromaticum (L.) Merr. \& L.M.Perry). Cloves (Syzygium aromaticum (L.) Merr. \& L.M.Perry) contains eugenol which is the main compound (72-90\%). Eugenol is a secondary metabolite that can be used as a bioreductor and capping agent in synthesizing AuNPs [13]. Clove flowers are showed in Figure 1.

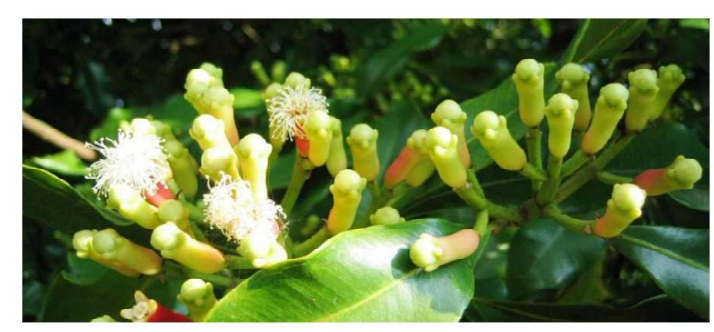

Figure 1. Syzygium aromaticum (L.) Merr. \& L.M.Perry

The AuNPs has attracted attention in recent years because of their widespread use. The AuNPs have a larger surface area, higher dispersion due to their very small size, stable and biocompatible. The AuNPs have tremendous benefits in medicine, for treatment of diabetes mellitus, cancer, cardiovascular disease, tuberculosis, and in controlling antibiotic resistance [1419]. Apart from the above benefits, AuNPs also have the ability to act as antioxidants [20], which, when used as dietary supplements it will have helped people fight the disorders like cardiovascular disease, aging, and cancer [21].

The antioxidant properties of the nanoparticles are important applications in therapeutic and biomedicine field [22-25]. There have been no reports of the antioxidant properties of AuNPs synthesized from Syzygium aromaticum (L.). We investigated the characterization of these AuNPs and their potential as antioxidants.

\section{EXPERIMENTAL METHOD}

\section{Materials and Instruments}

Materials used in this experiment: Syzygium aromaticum (L.) Merr. \& L.M.Perry flowers were obtained from the Negara Bali, Indonesia, and properly identified by the Indonesian Institute of Sciences, Bedugul, Bali, Indonesia. The $\mathrm{HAuCl}_{4}$ solution used as a precursor in this study was prepared by dissolving 99.99\% of pure Au metal (PT Antam) in aqua regia solution. 1,1-diphenyl-2-picrylhydrazyl (DPPH) for the antioxidant test was obtained from Nitra Kimia. Demineralised water (Aqua DM) was obtained from PT Brataco

The equipment used in this study were glassware (Pyrex), blender, hot plate (IKA C-MAG HS 7), analytical balance (Acis), filter paper, 50 mesh sieve, UV-Vis spectrophotometer (Genesys 10S UV-Vis) to measure the maximum wavelength of AuNPs, magnetic stirrer, zetasizer (Malvern) to determine the particle size, SEMEDS (JSM-6510LA) to investigate the morphology and content of the gold nanoparticles.

\section{Method and Procedure}

Five grams dried of Syzygium aromaticum (L.) Merr. \& L.M.Perry flowers were ground and blended with $100 \mathrm{~mL}$ of Aqua DM, then heated for 15 minutes at $60{ }^{\circ} \mathrm{C}$. The mixture was filtered with Whatman 42 filter paper. An extract concentration of $0.5 \%$ was prepared by diluting $100 \mathrm{~mL}$ of the filtrate in $1 \mathrm{~L}$ using the Aqua DM.

The synthesis of gold nanoparticles was carried out by mixing $0.5 \mathrm{mM} \mathrm{HAuCl}$ and $0.5 \%$ Syzygium aromaticum (L.) Merr. \& L.M.Perry flowers water extract with a ratio of $1: 10$. Then the solution is heated at $40^{\circ} \mathrm{C}$ and $80{ }^{\circ} \mathrm{C}$. As a visual indicator for the formation of 
AuNPs, the colloid changed color from clear yellow to cherry red. The AuNPs formed were characterized by some methods. First, the wavelength of gold nanoparticles was measured using a UV-Vis spectrophotometer (Genesys 10S UV-Vis) in the range of 400-800 $\mathrm{nm}$. The morphology and composition of the AuNPs was determined by scanning electron microscopy energy dispersive spectroscopy (SEM-EDS) (JEOL JSM-6510LA). The particle sizes were measured using dynamic light scattering technology (DLS) with a zetasizer (Malvern, UK).

The antioxidant activity of the AuNPs was studied by their free radical scavenging ability of DPPH [26]. Various concentrations colloid of AuNPs (10, 20, 30, 40, 50,60 , and $70 \mathrm{mg} / \mathrm{mL}$ ) were mixed with DPPH and incubated for 30 minutes. After 30 minutes, the absorbance of the solution was measured using a UVVis spectrophotometer at $517 \mathrm{~nm}$. For the blank used Aqua DM and DPPH without sample.

Antioxidant testing use synthesis temperature of $80 \mathrm{p} \mathrm{C}$, but the ratio between clove flower water extract and $\mathrm{HAuCl}_{4}$ solution varies based on the concentration to be made. From measurements using a UV-Vis spectrophotometer, all colloid concentrations must be showed a maximum wavelength between 500-600 nm, but the zetasizer test was not carried out for these 7 concentrations, so that the particle size of each concentration is not known with certainty. The formation of AuNPs was only suspected based on spectrophotometer UV-Vis measurements. The percentage of scavenging activity is calculated using equation (1).

Percent Scavenging Activity (\%) $=\frac{\text { Ablank }- \text { Asample }}{\text { Ablank }} \times 100$

\section{RESULTS AND DISCUSSION}

\section{The maximum wavelength of AuNPs}

AuNPs were synthesized using different synthesis temperatures. The purpose of this variation is to determine whether temperature has an effect in reducing gold nanoparticles. Measurements are carried out at wavelength range of 400-800 $\mathrm{nm}$ on days 1, 2, 3 of the synthesis so that the measurements were carried out 3 times.

The AuNPs formed under the two varied temperatures show the same maximum wavelength of $533 \mathrm{~nm}$. This proves that gold nanoparticles have been

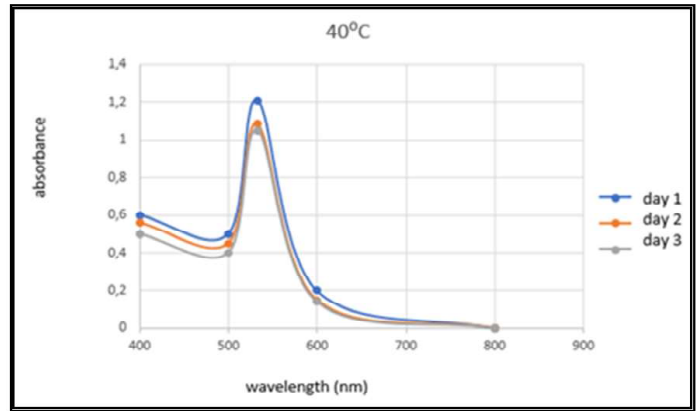

Figure 2. The absorbance of gold nanoparticles synthesized at $40{ }^{\circ} \mathrm{C}$

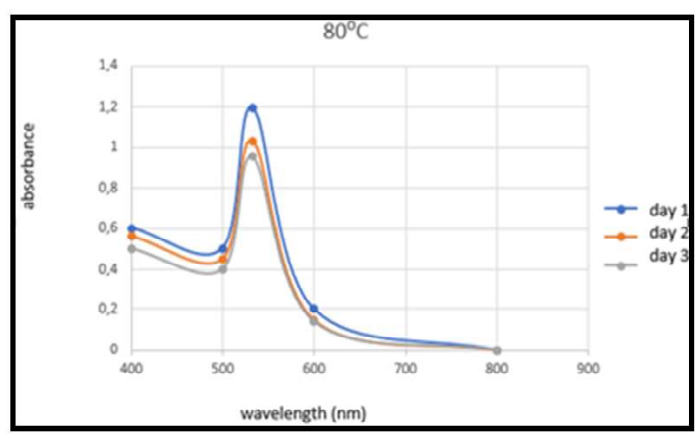

Figure 3. The absorbance of gold nanoparticles synthesized at $80{ }^{\circ} \mathrm{C}$

formed since they have maximum absorbances at a wavelength between 500-600 nm [27]. Surface plasmon resonance peak analyzed using the UV-Vis spectrum showed a peak at a wavelength of $533 \mathrm{~nm}$ (Figures 2 and 3 ). The flower of Syzygium aromaticum (L.) Merr. \& L.M.Perry succeeded in synthesizing AuNPs where the maximum wavelength of these AuNPs is $533 \mathrm{~nm}$ with a color change to cherry red. AuNP exhibits surface plasmon resonance due to oscillation of free electrons in the presence of a specific wavelength of light. in AuNP, a change in color was observed from yellow to cherry red and in some cases light to purple, depending on the shape and size of the nanoparticles. Phenomena of surface plasmon resonance on gold nanoparticles occur in visible light (500$600 \mathrm{~nm}$ wavelength) [28-30]. In Figure 4, it can be seen that the secondary metabolite components of plant extracts are responsible for reducing metal salts which will later lead to the growth and stability of gold nanoparticles [31-33].

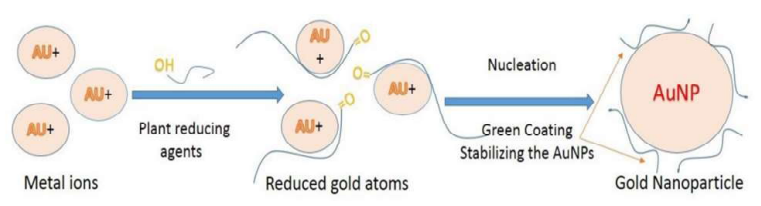

Figure 4. Biosynthesis of AuNPs with plant extract

After a statistical test was carried out on the effect of synthesis temperature on the formation of gold nanoparticles (Table 1), it was concluded that 
sig $(2$-tailed $)>0.05$ so that the different synthesis temperatures did not give a difference in results for the gold nanoparticle wavelength analysis. It can be concluded that the synthesis temperatures of $40{ }^{\circ} \mathrm{C}$ and $80{ }^{\circ} \mathrm{C}$ both produce gold nanoparticles which have a maximum wavelength of $533 \mathrm{~nm}$.

Table 1. Results of statistical tests on the effect of synthesis temperature on the maximum wavelength of AuNPs

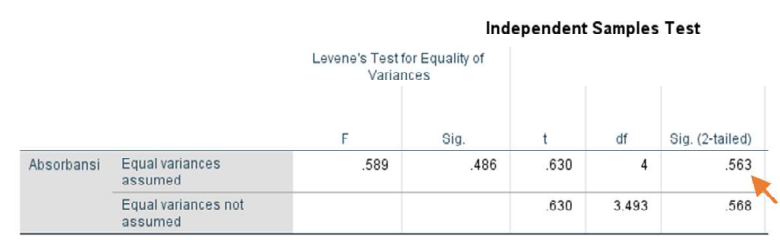

\section{Particle Size Analysis}

Samples of AuNPs synthesized under both temperatures were analyzed by zetasizer. Table 2 shows the results of the analysis.

Table 2. Results of Particle Size Analyzer

\begin{tabular}{lcc}
\hline & AuNPs (40 $\left.{ }^{\circ} \mathrm{C}\right)$ & AuNPs (80 $\left.{ }^{\circ} \mathrm{C}\right)$ \\
\hline Particle size (nm) & 109.83 & 73.52 \\
Polydispersity & 0.439 & 0.431 \\
Index & & \\
\hline
\end{tabular}

Table 2 shows that the particle sizes vary with temperature. The higher of reaction temperature, the size gold nanoparticles formed get smaller. Synthesis nanoparticles at higher temperatures produce particles with the average size smaller where the smallest AuNPs size was obtained through $73.52 \mathrm{~nm}$. This is because the higher temperature $\left(50{ }^{\circ} \mathrm{C}-100{ }^{\circ} \mathrm{C}\right)$, most of the gold ions are formed turns into a gold nanoparticle nucleus (nuclei) and inhibits further reduction reaction processes on the surface of the pre-formed nulcei [34]. The smallest AuNPs size obtained was $73.52 \mathrm{~nm}$ with polydispersity index value 0.431 . Polydispersity index shows the uniformity of the particle sizes. The smaller polydispersity index value, state that the more homogeneous the particle size [35]. The polydispersity index value greater than 0.5 indicates heterogeneity size of AuNPs. The results of the PSA showed that the nanoparticles obtained were in accordance with the literature. The particle size distribution can be seen in Figure 5 and 6. In Figure 5, there are 2 peaks. This is because the particle size is not evenly distributed where the PDI is 0.439 . There are 2 peaks below $100 \mathrm{~nm}$ and above $100 \mathrm{~nm}$, but the size of AuNPs above $100 \mathrm{~nm}$ is more dominant.

After a statistical test was carried out on the ef-

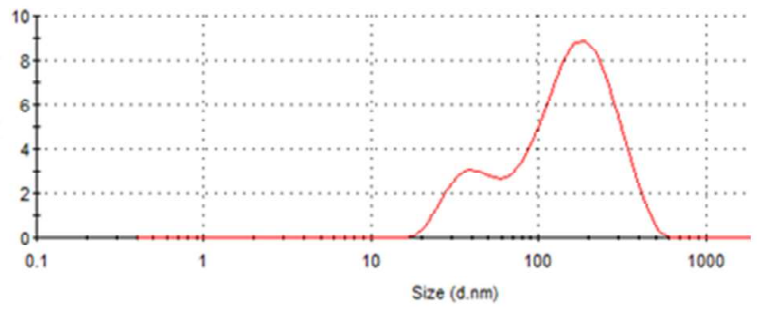

Figure 5. Particle size distribution of AuNPs in $40{ }^{\circ} \mathrm{C}$

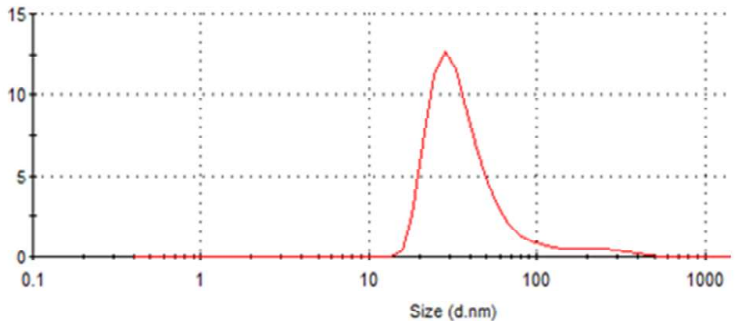

Figure 6. Particle size distribution of AuNPs in $80{ }^{\circ} \mathrm{C}$

fect of synthesis temperature on the formation of gold nanoparticles (Table 3 ), it was concluded that sig (2-tailed) $<0.05$ so that the different synthesis temperatures did give difference results for the gold nanoparticle sizes. It can be concluded that the synthesis temperature of $40^{\circ} \mathrm{C}$ and $80^{\circ} \mathrm{C}$ resulted in different sizes of gold nanoparticles where at $40^{\circ} \mathrm{C}$ the size of gold nanoparticles obtained was $109.83 \mathrm{~nm}$ while at $80{ }^{\circ} \mathrm{C}$ the size of gold nanoparticles obtained was $73.52 \mathrm{~nm}$.

Table 3. The results of statistical tests of the effect of synthesis temperature on the particle size of AuNPs

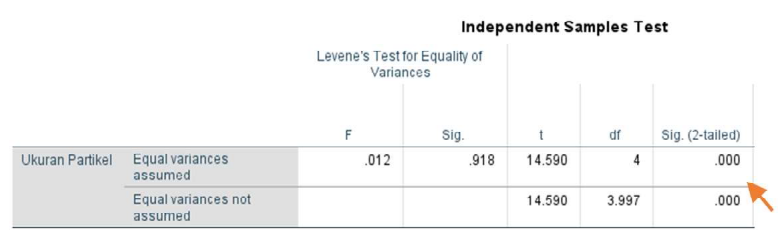

\section{Scanning Electron Microscopy Energy Dispersive X-Ray Spectroscopy}

Figure 7 and 8 shows a SEM image of AuNPs at the nanometric scale and clearly shows that the synthesized AuNP is spherical. SEM images of AuNPs formed after cessation of the reaction between Syzygium aromaticum (L.) Merr. \& L.M.Perry and $\mathrm{HAuCl}_{4}$ solution. From Figure 7 and 8, it is evident that the AuNPs are spherical with a diameter about $73.52 \mathrm{~nm}$.

Result obtained from the EDS provides a clear indication of nanoparticle elements. The strong signal of the gold atom confirmed that the gold nanoparticles contained pure gold (Figure 9). Typical optical absorption is between $2-4 \mathrm{KeV}$ confirms metal nanoparticles due to surface plasmon resonance [36]. Other element 


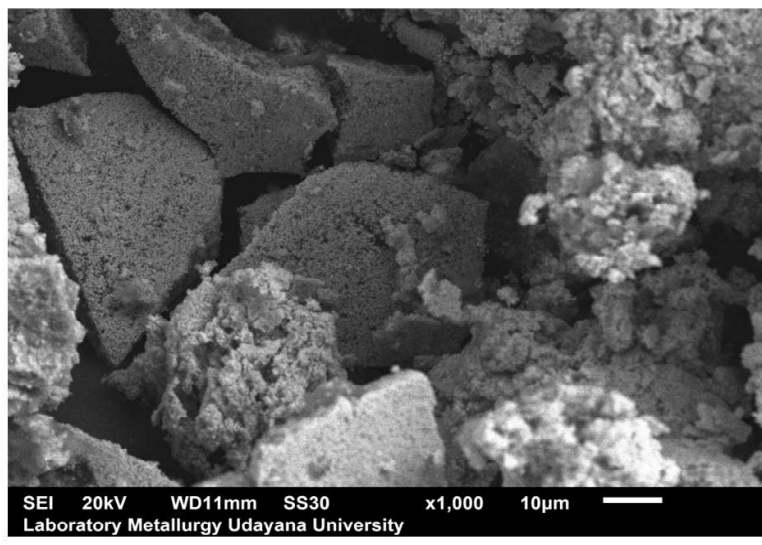

Figure 7. SEM image of AuNPs with magnification of $1.000 \mathrm{x}$

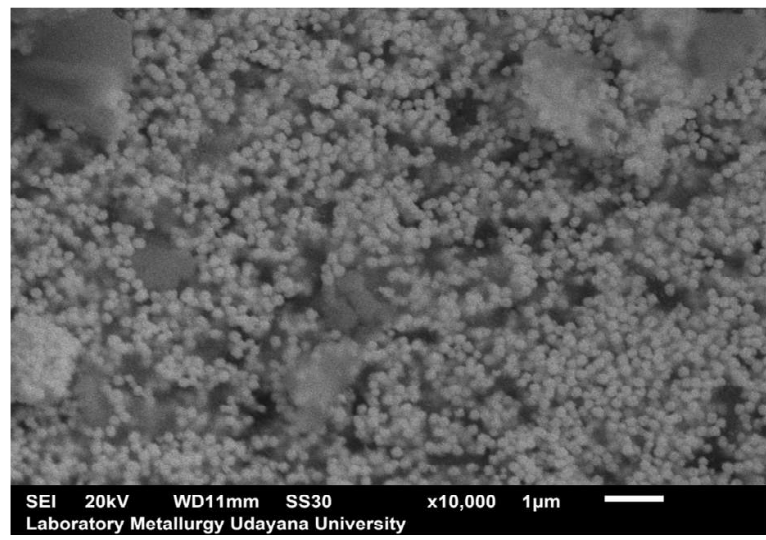

Figure 8. SEM image of AuNPs with magnification of $10.000 \mathrm{x}$

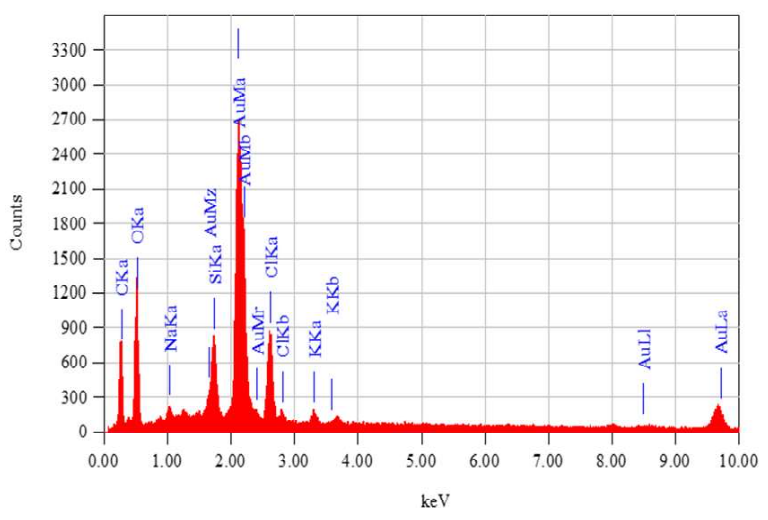

Figure 9. The composition of AuNPs determined by EDS

signals on the EDS spectrum is derived from plant secondary metabolites which function as stabilizing agents.

\section{Antioxidant Activity of AuNPs}

DPPH can change color from purple to yellow due to reduction by hydrogen or electrons [37]. In the DPPH free radical reduction test, compounds that can reduce DPPH are considered as antioxidants. In the antioxidant analysis, it is shown that the AuNPs are able to react with free radicals because they have antioxidant activity. Figure 11 represents the percentages of DPPH scavenging activities. Samples can be seen in Figure 10.

Gold nanoparticles showed the ability to react with free radicals at several concentrations. The percentage of free radical reduction by AuNPs is good, above $30 \%$ and up to $70 \%$. The antioxidant activity of gold nanoparticles highly dependent on the surface area. The smaller the particle size, the larger the surface area, and thus the higher the antioxidant activity [38]. Gold nanoparticles are smaller, have a larger total surface area, are more efficient in the antioxidant activity test. Free radical scavenging reaction mechanism from nanoparticles gold is gold nanoparticles giving electrons or hydrogen to free radicals thus free radicals become stable [39].

From Figure 11, it is apparent that the free radical scavenging ability increase from 10 to $30 \mu \mathrm{g} / \mathrm{mL}$ AuNPs, and then tend to decrease with increasing concentrations up to $70 \mu \mathrm{g} / \mathrm{mL}$. This is probably because the formation of the nanoparticles is incomplete. Formation imperfections can occur because the stirring is not stable, ratio between extract and $\mathrm{HAuCl}_{4}$, either the duration or the speed. Moreover, perhaps in the higher concentrations the particles aggregate more, hence decreases the surface area. This is because the higher concentration, the more gold particles formed, resulting in more collisions [40]. Based on the results of

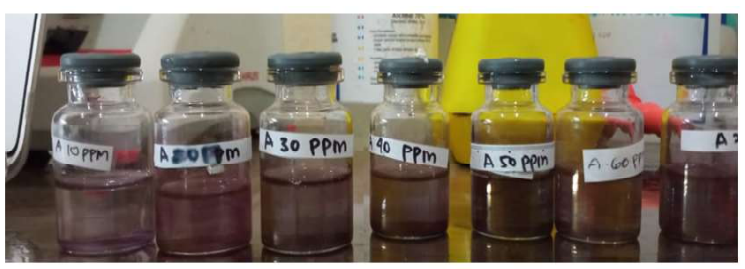

Figure 10. Samples with various concentrations

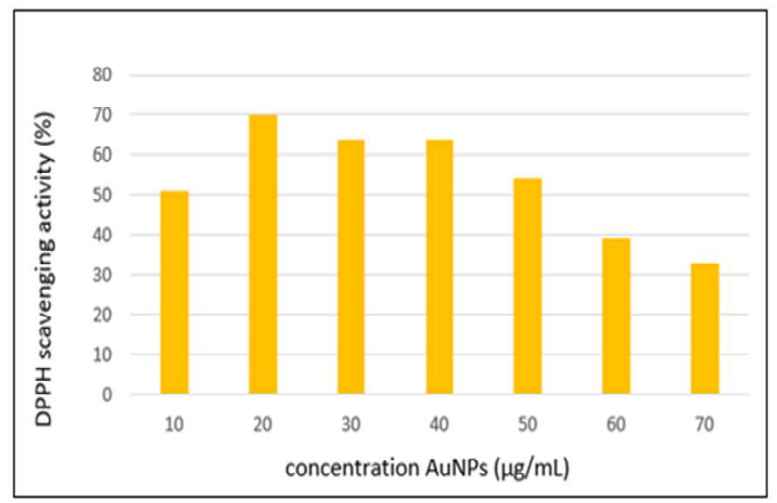

Figure 11. Antioxidant activity of AuNPs 
Figure 11, the $\mathrm{IC}_{50}$ of NPAu is 26.28 ppm where NPAu is classified as a very strong antioxidant.

\section{CONCLUSION}

This study finds that the Syzygium aromaticum (L.) flowers water extract has been successfully used to synthesize gold nanoparticles with a maximum wavelength of $533 \mathrm{~nm}$, have a spherical crystal morphology with the main component of gold. The particle size obtained by the synthesis at $80 \mathrm{p} \mathrm{C}$ is $73.52 \mathrm{~nm}$. The gold nanoparticles show antioxidant activity with free radical scavenging up to $70 \%$ and $\mathrm{IC}_{50}$ is $26.28 \mathrm{ppm}$.

\section{ACKNOWLEDGEMENT}

We wish to thank PT DKSH Jakarta (Wiji Rahayu S.Si.) for providing access to particle size analyzer.

\section{REFERENCES}

[1]. A. Husen, Q.I. Rahman, and M. Iqbal, M.O. Yassin, and R.K. Bachheti. "Plant-Mediated Fabrication of Gold Nanoparticles and Their Applications", in Nanomaterials and Plant Potential. Switzerland AG: Springer, Cham, 2019, pp.71-110.

[2]. A. Husen and K.S. Siddiqi. "Phytosynthesis of nanoparticles: concept, controversy and application.” Nanoscale Research Letters, vol 9, 229, May 2014.

[3]. K.S. Siddiqi, A. Husen, and R.A.K. Rao. "A review on biosynthesis of silver nanoparticles and their biocidal properties." Journal of Nanobiotechnology, vol. 16, Feb. 2018.

[4]. V.V. Makarov, A.J. Love, O.V. Sinitsyna, S.S. Makarova, I.V. Yaminsky, and M.E. Taliansky. “"Green" nanotechnologies: synthesis of metal nanoparticles using plants." Acta Naturae, vol. 6, pp.35-44, Mar. 2014.

[5]. M. Iqbal, R. Parveen, A. Parveen, B. Parveen, and I.M. Aref. "Establishing the botanical identity of plant drugs based on their active ingredients under diverse growth conditions." Journal of Environmental Biology, vol. 39, pp.123-136, Jan. 2018.

[6]. S. Ghosh, S. Patil, M. Ahire, R. Kitture, S. Kale, and K. Pardesi. "Synthesis of silver nanoparticles using Dioscorea bulbifera tuber extract and evaluation of its synergistic potential in combination with antimicrobial agents." International Journal of
Nanomedicine, vol.7, pp.483-496, Feb 2012.

[7]. R. Singh, P. Wagh, S. Wadhwani, S. Gaidhani, A. Kumbhar, and J. Bellare. "Synthesis, optimization and Characterization of silver nanoparticles from Acinetobacter calcoaceticus and their enhanced antibacterial activity when combined with antibiotics." International Journal of Nanomedicine, vol.8, pp.4277-4290, Nov. 2013.

[8]. U. Shedbalkar, R. Singh, S. Wadhwani, S. Gaidhani, and B.A. Chopade. "Microbial synthesis of gold nanoparticles: current status and future prospects." Advances in Colloid and Interface Science, vol.209, pp.40-48, Jul. 2014.

[9]. S.A. Wadhwani, U.U. Shedbalkar, R. Singh, M.S. Karve, and B.A. Chopade. "Novel polyhedral gold nanoparticles: green synthesis, optimization and characterization by environmental isolate of Acinetobacter sp SW30." World Journal of Microbiology and Biotechnology, vol. 30, pp.27232731, Jul. 2014.

[10]. Y.G. Yuan, Q.L. Peng, and S. Gurunathan. "Effects of silver nanoparticles on multiple drug-resistant strains of Staphylococcus aureus and Pseudomonas aeruginosa from mastitis-infected goats: an alternative approach for antimicrobial therapy. International Journal Molecular Science, vol. 18, pp. 569, Mar. 2017.

[11]. Z. Molnár, V. Bódai, G. Szakacs, B. Erdélyi, Z. Fogarassy, and G. Sáfrán. "Green synthesis of gold nanoparticles by thermophilic filamentous fungi." Scientific Reports, vol.8, Mar. 2018.

[12]. S. Onitsuka, T. Hamada, and H. Okamura. "Preparation of antimicrobial gold and silver nanoparticles from tea leaf extracts." Colloids and Surfaces B: Biointerfaces, vol. 173, pp 242-248, Jan. 2019.

[13]. F. Dehgani, A. Heshmatpour, M. Panjehshahin and T.T. Khozani. "Toxic effects of water/ alcoholic extract of syzygum aromaticum on sperm quality, sex hormones and reproductive tissues in male mouse.” European Journal of Biology, vol. 71 (2): pp.95-102, Dec. 2012.

[14]. D.A. Giljohann, D.S. Seferos, W.L. Daniel, M.D. Massich, P.C. Patel, and C.A. Mirkin. "Gold nanoparticles for biology and medicine." Angewandte Chemie (International ed. in English), vol. 49, vol. 19, pp.3280-94, Feb. 2010.

[15]. S. Ghosh, P. More, A. Derle, A.B. Patil, P. Markad, and A. Asok. "Diosgenin from Dioscorea bulbifera: novel hit for treatment of type II diabetes mellitus 
with inhibitory activity against á-amylase and áglucosidase.” PloS ONE, vol. 9, Sep. 2014.

[16]. A. Mallick, P. More, S. Ghosh, R. Chippalkatti, B.A. Chopade, and M. Lahiri. "Dual drug conjugated nanoparticle for simultaneous targeting of mitochondria and nucleus in cancer cells." ACS Applied Materials \& Interfaces, vol.7, pp.758407598, Mar. 2015.

[17]. R. Singh, N. Laxman, M. Arkile, S. Wadhwani, U. Shedbalkar, and B.A. Chopade. "Phytogenic silver, gold, and bimetallic nanoparticles as novel antitubercular agents." International Journal of Nanomedicine, vol. 11, pp.1889-1897, May 2016.

[18]. S.A. Wadhwani, M. Gorain, P. Banerjee, U.U. Shedbalkar, R. Singh, and G.C. Kundu. "Green synthesis of selenium nanoparticles using Acinetobacter sp. SW30: optimization, characterization and its anticancer activity in breast cancer cells." International Journal of Nanomedicine, vol. 12, pp.6841-6855, Sep. 2017.

[19]. R. Kitture, K. Chordiya, S. Gaware, S. Ghosh, P.A. More, and P. Kulkarni. " $\mathrm{ZnO}$ nanoparticles-red sandalwood conjugate: a promising anti-diabetic agent." Journal of Nanoscience and Nanotechnology, vol.15, pp.4046-4051, Jun. 2014.

[20]. G. Bjelakovic, D. Nikolova, and C. Gluud. "Antioxidant supplements and mortality." Current Opinion in Clinical Nutrition \& Metabolic Care, vol. 17,pp.40-44, Jan. 2014.

[21]. R. Madhanraj, M. Eyini, and P. Balaji. "Antioxidant assay of gold and silver nanoparticles from edible basidiomycetes mushroom fungi." Free Radicals Antioxidants, vol. 7, Mar. 2017.

[22]. R. Kitture, K. Chordiya, S. Gaware, S. Ghosh, P.A. More, and P. Kulkarni. "ZnO nanoparticles-red sandalwood conjugate: a promising anti-diabetic agent. Journal of Nanoscience and Nanotechnology, vol. 15, pp. 4046-4051, Jun. 2014.

[23]. G.R. Salunke, S. Ghosh, K. Santosh, S. Khade, P. Vashisth, and T. Kale. "Rapid efficient synthesis and characterization of silver, gold, and bimetallic nanoparticles from the medicinal plant Plumbago zeylanica and their application in biofilm control." International Journal of Nanomedicine, vol. 9, pp.2635-2653, May 2014.

[24]. S. Ghosh, P. More, A. Derle, R. Kitture, T. Kale, and M. Gorain. "Diosgenin functionalized iron oxide nanoparticles as novel nanomaterial against breast cancer." Journal of Nanoscience and Nanotechnology, vol. 15, pp. 9464-9472, Dec. 2015.
[25]. S. Ghosh, and M.J Chacko. "Barleria prionitis leaf mediated synthesis of silver and gold nanocatalysts." Journal of Nanomedicine \& Nanotechnology, vol. 7, Aug. 2016.

[26]. P. Molyneux. "The use of stable free radical diphenylpicryhydrazyl (DPPH) for estimating antioxidant activity." Journal of Science Technology, vol 26, pp. 211-219, Dec. 2003.

[27]. G. Manjari, S. Saran, T. Arun, P. Suja, A. Devipriya, and V.B. Rao. "Facile aglaia elaeagnoidea mediated synthesis of silver and gold nanoparticles: antioxidant and catalysis properties." Journal of Cluster Science, vol. 28, pp.2041-2056, Mar. 2017

[28]. B. ElDeeb, N.Y. Mostafa, S.Tork, and N. ElMemoni. "Optimization of green synthesis of gold nanoparticles using bacterial strain alcaligenes faecalis." Nanoscience and Nanotechnology Letters, vol. 6, pp.1-13, May 2014.

[29]. D. Anggraini, S. Suhartati, I.S. Saputra, and Sudirman. "Gold nanoparticles and their interaction study with metformin." Jurnal Sains Materi Indonesia, vol. 21(2), pp.56-61, Jul. 2020.

[30]. I.E. Suprihatin, G.A.D. Lestari, R. Mardhani, V. Edoway. "Silver nanoparticles (AgNPs) as photocatalyst in the photodegradation of rhemazol brilliant blue.” IOP Conf. Ser.: Ma-ter. Sci. Eng. 959. 012018, 2020

[31]. E.H. Ismail, A.M.A. Saqer, E. Assirey, A. Naqvi, and R.M. Okasha. "Succesful green synthesis of gold nanoparticles using a Corchorus olitorius extract and their antiproliferative effect in cancer cells.” International Journal of Molecular Science, vol.19(9), Sep. 2018

[32]. I.S. Saputra, Y.Yulizar, and Sudirman. "Effect of Concentration of Imperata cylindrica L. leaf extract on synthesis process of gold nanoparticles." Jurnal Sains Materi Indonesia, vol. 19(2), pp.7276, 2018.

[33]. S. Suhartati, I.S. Saputra, D. Rahmi, Y. Yulizar, and Sudirman. "Bioreduction and characterization of silver nanoparticles from oil palm empty fruit bunch.” Jurnal Sains Materi Indonesia, vol. 21(4), pp 177-183, Dec. 2020.

[34]. G.A.D. Lestari, I.E. Suprihatin, and J. Sibarani. "Synthesis of silver nanoparticles (npag) using andaliman (Zanthoxylum acanthopodium DC.) fruit water extract and its application in indigosol blue photodegradation.” Jurnal Kimia Sains dan Aplikasi, vol. 22, no. 5, pp. 200-205, Sep. 2019

[35]. Y. Yuan, Y.X. Gao, J. Zhao, and L. Mao. 
"Characterization and stability evaluation of $\alpha$-carotene nanoemulsions prepared by high pressure homogenization under various emulsifying conditions." Food Research International, vol. 41, pp.61-68, Sep. 2008.

[36]. P. Magudapatty, P. Gangopadhyayrans, B.K. Panigrahi, K.G.M. Nair, and S. Dhara. "Electrical transport studies of $\mathrm{Ag}$ nanoclusters embedded in glass matrix." Physica B: Condensed Matter, vol. 299, pp.142-146, May 2001.

[37]. S. Medhe, P. Bansal, and M.M. Srivastava. "Enhanced antioxidant activity of gold nanoparticle embedded 3,6-dihydroxyflavone: a combinational study.” Applied Nanoscience, vol. 4, pp.153-161, Feb. 2014.
[38]. S. Sharma, A.K. Manhar, P.J. Bora, S.K. Dolui, and M. Mandal. "Evaluation of antioxidant and antibacterial activity of various aspect ratio gold (Au) nanorods." Advanced Materials Letters, vol. 6, pp.235-241, 2015.

[39]. M.H. Oueslati, L.B. Tahar, and A.H. Harrath. "Catalytic, antioxidant and anticancer activities of gold nanoparticles synthesized by kaempferol glucoside from Lotus leguminosae." Arabian Journal of Chemistry, vol. 13, pp.3112-3122, Jan.2020.

[40]. E. Musfiroh, and S.H. Syarief. "Free radical scavenging of activity test of gold nanoparticles with various concentrations as antiaging material in cosmetics." Unesa Journal of Chemistry, vol. 1, pp.18-25, 2012. 